was also seen to be unfair. It could not be justified in terms of the limitation clause, since the aim of the provincial government to reduce unemployment among South African teachers at the expense of permanent residents would be illegitimate (Larbi-Odam decision, para. 31).

Although the outcome of the decision is to be welcomed, one might ask what the fate of the permanent residents would have been, had they not been perceived as a vulnerable group whose fundamental dignity might be at stake. Had they not passed this hurdle, the impact of the regulation on their interests and the idiosyncrasy of granting people permanent residency and then excluding them from the employment market, might not have been considered at all.

\section{CONCLUSION}

In the final analysis, the main criticism against the historical interpretation followed by the court is that it results in a very restrictive concept of equality. Only those categories of persons who would qualify as a vulnerable group, or whose fundamental dignity could be affected by the discriminatory measures, have a realistic chance of succeeding with a claim of unfair discrimination. It seems that the court assumes that treating less severe forms of discrimination as 'unfair discrimination' might trivialise the severity of the humiliating discrimination suffered by the country's black population in the past. Consequently, many patterns of less severe but nonetheless unfair treatment would be excluded from the protection provided by the equality clause, unless the court develops artificial constructions of vulnerable groups, or artificial connections between discriminatory measures and the fundamental dignity of those affected. The court would be well advised to reconsider this interpretation, if it is truly committed to providing extensive equal treatment to the members of the South African society. (c)

\section{Erika de Wet}

Swiss Institute of Comparative Law, Lausanne

\title{
Hong Kong
}

\section{Does legal set-off exist?}

\section{by Eugene Fung}

I Re Finbo Engineering Co Ltd (unreported), 18 March 1998, Le Pichon J, the Court of First Instance in Hong Kong was asked whether legal set-off exists in Hong Kong. A petition was filed to wind up a company on the ground that it was unable to pay its debts and that it was just and equitable that it should be wound up. The petition was opposed by the company on the ground that it was entitled to a set-off against the debt owed to the petitioner.

If the company" could show an arguable defence of legal set-off, the petition would have to be dismissed. Le Pichon J concluded that, given the complexity of the question, the company must at least have an arguable defence of legal set-off.

\section{ORIGINS OF LEGAL SET-OFF}

A 'set-off' has been defined as 'the setting of cross-claims against each other to produce a balance' (see R Derham, Set-Off, 2nd ed, (1996), Oxford, p. 1). Legal set-off has a statutory origin: the statutes of set-off were enacted in England in 1729 and 1735 ('the statutes of set-off'). Before the passing of the statutes of set-off, a debtor had to bring a separate action in order to enforce a debt owed to him by his creditor.

The statutes of set-off were designed to prevent the imprisonment as a debtor of a person not truly indebted because there was a mutual debt owing by his creditor. The plea of set-off under the statutes was available where each of the demands sounded in damages and was "capable of being liquidated, or ascertained with precision at the time of pleading'(Tindal CJ in Morley $v$ Inglis (1837) 4 Bing (NC) 58 at p. 71). (Recently, in Stein v Blake [1996] 1 AC 243 at p. 251, Lord Hoffmann similarly said that the "legal set-off is confined to debts which at the time when the defence of set-off is filed were due and payable and either liquidated or in sums capable of ascertainment without valuation or estimation.')

Moreover, the debtor did not have to bring his cross-claim in a separate action. Thus, as Willes CJ thought, the statutes of set-off were intended to avoid circuity of action (Hutchinson $v$ Sturges (1741) Willes 261 at p. 262).
The Supreme Court of Judicature in England was established by the Judicature Act 1873, which expressly allowed the court to entertain a counterclaim (s. 24, rule 3). It therefore appears that the passing of the Judicature Act 1873 rendered the statutes of set-off redundant. Accordingly, the statues of set-off were repealed by s. 2 of Civil Procedure Acts Repeal Act 1879 and the Statute Law Revision and Civil Procedure Act 1883. In each of the repealing statutes, there were savings to ensure that the repeal would not affect any jurisdiction, principle or rule of law or equity which had been established or confirmed by or under either of the enactments (Civil Procedure Acts Repeal Act 1879, s. 4(1)(b) and the preamble of the Statute Law Revision and Civil Procedure Act 1883). The saving provisions have been interpreted as preserving the right of set-off originally conferred by the statutes of set-off (e.g. Hanak $v$ Green [1958] 2 QB 9 at p. 22 where Morris LJ said that 'the Judicature Acts conferred no new rights of set-off'). It follows that the right to a legal set-off under the statutes of set-off had come to be regarded as part of the common law of England and Wales at the time when the statutes of set-off were repealed.

\section{LEGAL SET-OFF IN HONG KONG}

The Supreme Court of Judicature at Hong Kong was established by Ordinance No. 15 of 1844 ("the 1884 Ordinance'). Section 3 of the 1884 Ordinance reads:

And be it further enacted and ordained, That the Law of England shall be in full Force in the said Colony of Hong Kong, except where the same shall be inapplicable to the local Circumstances of the said Colony, or its Inhabitants: ... Provided also, that in all Matters relating to the Practice and Proceedings of the said Supreme Court... the Practice of the English Courts shall be in Force, until otherwise ordered by any Rule of the said Court...

Le Pichon J said in her judgment that:

"local circumstances would not have made the statutes [of set-off] inapplicable or subject to modification.'

Although the 1884 Ordinance was subsequently amended several times, the application of the statutes of set-off was not 
affected. In the present case, it was argued by the petitioner that legal set-off was not applicable in Hong Kong because the statutes of set-off were not listed in the schedule to the Application of English Law Ordinance (No. 2 of 1966) ('AELO'). (The AELO was to declare the extent to which English law was in force in Hong Kong; see generally P Wesley-Smith, The Sources of Hong Kong Law, (1994), Hong Kong, p. 91-95.) The AELO provided, inter alia:

- for the common law and the rules of equity to be enforced in Hong Kong so far as applicable and subject to any necessary modifications (s. 3);

- for certain English Acts as listed in the schedule to the Ordinance to apply to Hong Kong subject to such modifications as local circumstances warranted (s. 4).

Neither the statutes of set-off nor the 1879 and 1883 Acts have ever been listed in the schedule to the AELO. It was accepted by the petitioner that legal set-off was part of the law of Hong Kong for over 120 years (i.e. from 1844 - 1966). However, as a result of the passing of the AELO which excluded any English statues on legal set-off, it was argued that the doctrine of legal set-off was thereby abolished.

Le Pichon J did not decide on this question. Her Ladyship rightly pointed out that:

'it is wholly inappropriate to determine such an important question (viz. whether legal set-off was abolished by the AELO) in the context of an application to stay or dismiss winding-up proceedings. For present purposes, suffice to say that this question admits of no easy answer. So at a minimum, Finbo [the company] must at least have an arguable defence based on legal set-off, the existence of such right raising ' $a$ serious question'

\section{LEGAL SET-OFF NEVER ABOLISHED}

It is submitted that legal set-off has existed in Hong Kong since 1884 and was never abolished by the AELO in 1966 . When the 1844 Ordinance was enacted in Hong Kong, it was the practice and procedure of the English courts to allow claims of legal set-off as a defence. Such English practice was firmly established as part of the Hong Kong practice and procedure through the various Supreme Court Ordinances enacted between 1844 and 1937 (see s. 4 of the 1845 Ordinance, s. 3 of the 1846 Ordinance, s. 5 and 6 of the 1873 Ordinance and item 17(1) of the schedule to the 1937 Ordinance). Hence, up to 1966 before the enactment of the AELO, it is clear that legal set-off has been in existence in Hong Kong.

Section 7 of the AELO amended the previous Supreme Court Ordinance to read as follows:

'Subject to the provisions of this Ordinance, the practice of the Supreme Court of Judicature of England for the time being in force therein shall be in force in the court.

Accordingly, if legal set-off was firmly established as a matter of procedure both in England and Hong Kong before 1966, it would have clearly survived after the enactment of the AELO in 1966. It was unnecessary for the AELO to include any English statutes on legal set-off in its schedule. In fact, it would have been odd if the AELO had made the statutes of set-off applicable to Hong Kong because the statutes of set-off were simply no longer applicable in England in 1966.

The applicability of legal set-off in Hong Kong after 1966 is also clear. Section 17 of the Supreme Court Ordinance 1975 again confirmed the position of legal set-off in Hong Kong. The relevant provision in the current Supreme Court Ordinance is s. 16(2)(b) (substituted pursuant to s. 11 Supreme Court (Amendment) Ordinance 1987, commencing 10 July 1987. The wording of this section has the similar effect as s. 49 of the Supreme Court Act 1981). The effect of s. 16(2)(b) is simply to preserve the right to plead legal set-off in so far as the same was created and governed by the ordinances stretching from 1844-1987. It is submitted that legal set-off has been preserved by the various Supreme Court Ordinances. It could not have been abolished by the AELO in 1966 because the doctrine of legal set-off is a procedural defence, as opposed to being a substantive defence.

\section{DEFENCE OF LEGAL SET-OFF}

A substantive defence destroys the validity of the plaintiff's claim:

'either by requiring that the facts necessary to be proved in order to give rise to the claimed legal liability should be proved to the appropriate standard, or by showing that the facts (if proved) would not attract that liability.' (G Burton, 'Set-off', The Principles of Equity, ed P Parkinson, (1996), Sydney, 971 at p. 974)

On the other hand, a procedural defence only has effect until judgment.

The defence of set-off is clearly more akin to a procedural defence. The plaintiff's debt and the defendant's cross-claim remain distinct unless and until there is judgment for a set-off. In relation to legal set-off, it is submitted that it is a procedural defence (see Derham, who is of the view that the right of set-off derived from the statutes of set-off is not purely procedural because it can have a substantive effect upon the rights and interests of third parties). When legal set-off is pleaded as a defence, it amounts to an admission that the defendant is entitled to set off his cross-claim in reduction* or extinction of the amount for which the plaintiff is entitled to judgment (see R Goode, Legal Problems of Credit and Security, 2nd ed, (1988), p. 139, and Burton, 971 at p. 982). It has further been said that:

'[Set-off] is part of the law of procedure which enables a debtor in an action brought against him by his creditor to raise as a defence a cross-debt or liquidated demand. But a set-off is not a denial of the debt - it is a plea against its enforcement. It is in substance a plea in bar. It differs in substance from a plea of payment or accord and satisfaction which in effect alleges that the claim no longer exists. A plea of set-off, on the other hand, in effect admits the existence of the debt, but sets up a cross-claim as being a ground on which the person against whom the claim is brought is excused from payment and entitled to judgment on the plaintiff's claim.' (O'Bryan J in Re K L Tractors Ltd [1954] VLR 505 at p. 507; see also Stehar Knitting Mills Pty Ltd v Southern Textile Converters Pty Ltd (1980) 2 NSWLR 514 at $517 \mathrm{E}-\mathrm{F}, 518 \mathrm{~F}-\mathrm{G})$.

Accordingly, the set-off crystallises at the time of judgment and the plaintiff's claim is not reduced or extinguished until that time (Re Hiram Maxim Lamp Company (1903) 1 Ch 70).

It is also important to bear in mind the purpose for which the defence of legal set-off was created. As stated carlier, the statutes of set-off were designed to avoid circuity of action (see Hutchinson case), which is entirely a matter of procedure. Moreover, when the statutes of set-off were repealed in 1879 and 1883 in England, the very title of the repealing statutes suggested that at that stage, the legislature viewed legal set-off as a rule of procedure (S McCracken, The Banker's Remedy of Set-off (1993), London, p. 57). (See especially the preamble to Civil Procedure Acts Repeal Act 1879 which referred to 'certain enactments which relate to civil procedure or matters connected therewith'.)

Accordingly, being a procedural defence, legal set-off has been preserved by the various Supreme Court Ordinances and is alive and well in Hong Kong. (c)

Eugene T S Fung

Barrister, Hong Kong 